\title{
Mining in New Caledonia: environmental stakes and restoration opportunities
}

\author{
Guillaume Losfeld • Laurent L'Huillier • Bruno Fogliani • \\ Tanguy Jaffré • Claude Grison
}

\begin{abstract}
New Caledonia is a widely recognised marine and terrestrial biodiversity hot spot. However, this unique environment is under increasing anthropogenic pressure. Major threats are related to land cover change and include fire, urban sprawling and mining. Resulting habitat loss and fragmentation end up in serious erosion of the local biodiversity. Mining is of particular concern due to its economic significance for the island. Open cast mines were exploited there since 1873, and scraping out soil to access ores wipes out flora. Resulting perturbations on water flows and dramatic soil erosion lead to metal-rich sediment transport downstream into rivers and the lagoon. Conflicting environmental and economic aspects of mining are discussed in this paper. However, mining practices are also improving, and where impacts are inescapable ecological restoration is now considered. Past and ongoing experiences in the restoration of New Caledonian terrestrial ecosystems are presented and discussed here. Economic use of the local floristic diversity could also promote conservation and restoration, while providing alternative incomes. In this regard, Ecocatalysis, an innovative approach to make use of metal hyperaccumulating plants, is of particular interest.
\end{abstract}

G. Losfeld $\cdot$ C. Grison $(\triangle)$

FRE 3673-Bioinspired Chemistry and Ecological InnovationCNRS, University of Montpellier 2, Stratoz, Cap Alpha, Avenue de l'Europe, 34830 Clapiers, France

e-mail: claude.grison@cnrs.fr

L. L'Huillier · B. Fogliani

Diversités biologique et fonctionnelle des écosystèmes terrestres, Institut Agronomique néo-Calédonien (IAC), 98890 Païta, New Caledonia

T. Jaffré

UMR AMAP, IRD, Laboratoire de Botanique et d'Ecologie Végétale Appliquées, Institut de recherche pour le développement, 98848 Noumea, New Caledonia
Keywords Ecological restoration · Conservation · Ecocatalysis $\cdot$ Phytoextraction $\cdot$ Nickel $\cdot$ Manganese

\section{Introduction}

In 1864, Jules Garnier discovered an unknown green rock on the Dumbea River, north of Noumea, New Caledonia. This rock was found to be a Ni-Mg silicate and contained about $15 \% \mathrm{Ni}$ (weight ratio): It was later named Garnierite for Mr. Garnier. Garnier's discovery was the starting point of nickel exploitation in New Caledonia: First mining operations are reported in 1873 on the MontDore, and the first ore treatment plant was built in 1877 at Pointe Chaleix in Noumea (L'Huillier et al. 2010). Société Le Nickel (SLN) was founded in 1880 and remained the world largest nickel producer until 1905, when exploitation of the Sudbury deposit started in Canada. To date, SLN is still a world class operator of the nickel industry: The Doniambo smelter built in 1910 was still the second largest Ni laterite producer by 2008 (Mudd 2010). According to the latest estimates by the US Geological Survey (USGS), New Caledonia is currently the fifth producer of nickel in the world and may account for $16 \%$ of acknowledged nickel reserves (USGS 19962013). Thus, the nickel industry should remain a major component of the island's economy in the upcoming decades.

In spite of its industrial reputation, New Caledonia is also a widely recognised biodiversity hot spot (Myers 1988; Myers et al. 2000) and is sometimes referred to as a living museum (Mittermeier et al. 1996). The marine environment there is highly regarded, and lagoons of New Caledonia are now listed as World Heritage Sites (UNESCO 2013). As regard to terrestrial ecosystems, New Caledonia is of particular interest to study plant 
evolution and diversification. The island has a unique and original flora: Latest studies reported 3,371 vascular plant species, $74.7 \%$ of them being endemic to the archipelago (Morat et al. 2012). The main island, known as Grande Terre, probably separated from Gondwana during Late Cretaceous (80-100 Ma), was submerged during Palaeocene and Early Eocene and re-emerged during Late Eocene (37 Ma), creating a large ultramafic ophiolitic nappe covering the total surface are of Grande Terre, Belep and Isle of Pines (Pelletier 2006). Subsequent biological colonisation by long-distance dispersal occurred (Grandcolas et al. 2008; Pillon et al. 2010), with a high endemism driven by insularity, the high geological diversity and variations in climatic conditions, including rainfall patterns and altitude (Grandcolas et al. 2008; Jaffre 1993; Wulff et al. 2013). According to molecular clocks, numerous clades colonised the island much later than 37 Ma (Barrabe et al. 2014; Pillon 2012), which highlights the complex evolutionary pathways of the biota of New Caledonia and the interest of considering speciation, as well as possible extinctions. Most recent studies of the local flora focussed on Amborella trichopoda, whose genome could improve our general understanding of flowering plants (Amborella Genome Project 2013).

As regards to conservation, sclerophyll forests mainly on non-ultramafic substrates were the first strongly endangered terrestrial ecosystem from New Caledonia, because they were suitable for agriculture (Bouchet et al. 1995). However, emphasis is now shifting to the flora on ultramafic substrates (Pascal et al. 2008), an aspect discussed in details herein. Apart from hosting major nickel reserves, ultramafic outcrops from New Caledonia also host a unique biodiversity: So far, 2,153 plant species have been identified on such soils, with an endemism of $88 \%$. A total of 1,160 plant species, $95 \%$ endemic, are strictly restricted to ultramafic areas (L'Huillier et al. 2010), which highlights the major interest of this flora. Species of particular interest such as nickel hyperaccumulators were discovered for the first time in New Caledonia on ultramafic substrates (Jaffre et al. 1976): They are particularly abundant there (Jaffre et al. 2013) and provide material for the fundamental understanding of metal hyperaccumulation (Merlot et al. 2014). Potential applications of nickel hyperaccumulators in phytomining (Chaney et al. 2007; van der Ent et al. 2013b) or Ecocatalysis, an innovative and promising Green Chemistry process (Escande et al. 2013; Escande et al. 2014a, b; Grison et al. 2014; Grison and Escande 2013a, b, c; Grison and Escarre 2011a, b; Losfeld et al. 2012a, b, c; Thillier et al. 2013) have raised awareness about their conservation: They may serve as flagship species for the metallophyte biodiversity, which is particularly threatened by mining operations (Whiting et al. 2004).

\section{Significance of mining for New Caledonia}

\section{Geological characteristics}

New Caledonia is an archipelago located in the Southwest Pacific (20-23 S, 164-167 E), northeast of mainland Australia, and southwest of Vanuatu. The main islands are located along two northwest-southeast ridges: Belep, Grande Terre (the main island) and Isle of Pines are on the New Caledonia ridge, while the Loyalty Islands, Lifou, Maré, Ouvéa and Tiga are on the Loyalty ridge. Two major tectonic events resulted in terranes found on the New Caledonia ridge: a Late Jurassic to Early Cretaceous tectonic collage and a Late Eocene subduction-collusion, overthrusting a large ultramafic ophiolitic nappe (Pelletier 2006). Lateritisation, i.e. the tropical weathering of this nappe mainly composed of peridotite (harzburgite, dunite), produced Ni-rich laterites, as well as other ultramafic substrates. In the lateritisation process, most soluble elements such as $\mathrm{K}, \mathrm{Na}, \mathrm{Mg}, \mathrm{Ca}$ or $\mathrm{Si}$ are washed, while less soluble elements such as $\mathrm{Fe}, \mathrm{Al}$, $\mathrm{Ni}$ or Co remain. Lateritisation is quick under tropical conditions and occurs in a two-step process: (i) dissolution of $\mathrm{Si}$ and $\mathrm{Mg}$ contained in pyroxene and olivine, with accumulation of $\mathrm{Fe}$ as oxyhydroxydes and (ii) recombination of $\mathrm{Si}$ and $\mathrm{Mg}$ as smectite clays. The first step produces ferritic ferralsols, which may be referred to as Ni-rich laterites, or 'terrains miniers' according to the local French denomination. The second step occurs in drier conditions and results in magnesic cambisols usually found at the base of the massifs (Fritsch 2012; Latham et al. 1978). Typical composition of ferritic ferralsols compared to magnesic cambisols can be found in Table 1: They mainly differ by their cation exchange capacity (CEC), higher for magnesic cambisols, due to higher exchangeable $\mathrm{Mg}$.

The exceptional biodiversity of New Caledonia is often thought to result from the sole action of soil nickel as a major speciation driver. Yet, soils produced by lateritisation are not only ferritic ferralsols, as discussed in studies by Latham et al. (1978). Magnesic cambisols provide a meaningful example: They also host a unique biodiversity, although they are not subject to mining (Jaffré 1980; Latham et al. 1978). Thus, magnesic cambisols are geologically and ecologically different from Ni-rich laterites, as observed later in other areas (Alexander 2009). Grande Terre is also covered by nonultramafic soils, after total erosion of $70 \%$ of the initial surface area of the ophiolitic nappe (Pelletier 2006). The fact that New Caledonia has a unique biodiversity is due to insularity, climate (rainfall and altitude) and mountain reliefs (altitude and vicariance) (Grandcolas et al. 2008; Jaffre 1993; Wulff et al. 2013), and also but not only to the high edaphic diversity on ultramafic and non-ultramafic substrates (Jaffré 1980; Latham et al. 1978; Wulff et al. 2013).

Mining in New Caledonia targets ferritic ferralsols, which present a typical profile (Fig. 1): The top surface is made of an 
Table 1 Typical composition of the upper horizon $(0-20 \mathrm{~cm})$ of ferritic ferralsols found at the 'Camp des Sapins' mine, New Caledonia; mine tailings produced at 'Camp des Sapins'; and magnesic cambisols found in New Caledonia

\begin{tabular}{|c|c|c|c|c|c|c|c|}
\hline & & \multicolumn{2}{|c|}{ Ferritic ferralsol $(n=12)$} & \multicolumn{2}{|c|}{ Mine tailings $(n=12)$} & \multicolumn{2}{|c|}{ Magnesic cambisol $(n=80)$} \\
\hline & & Mean & SD & Mean & $\mathrm{SD}$ & Mean & SD \\
\hline & $\mathrm{pH}$ & 6.4 & 0.1 & 7.7 & 0.2 & 6.81 & 0.5 \\
\hline & $\% \mathrm{~N}$ & 0.04 & 0.01 & 0.01 & 0.00 & na & na \\
\hline & $\% \mathrm{C}$ & 1.33 & 0.28 & 0.37 & 0.14 & na & na \\
\hline & CEC (meq\%) & 4.68 & 0.48 & 6.88 & 0.93 & 40.9 & 18.2 \\
\hline \multirow[t]{4}{*}{ Exchangeable cations (meq\%) } & $\mathrm{Ca}$ & 0.32 & 0.12 & 0.13 & 0.04 & 2.35 & 2.31 \\
\hline & $\mathrm{Mg}$ & 3.71 & 1.11 & 9.76 & 2.30 & 33.5 & 15 \\
\hline & $\mathrm{Na}$ & 0.02 & 0.01 & 0.03 & 0.02 & 0.35 & 0.19 \\
\hline & $\mathrm{K}$ & 0.04 & 0.01 & 0.05 & 0.05 & 0.22 & 0.17 \\
\hline \multirow[t]{2}{*}{ Phosphorus (mg/kg) } & Available & 53.5 & 6.9 & 40.5 & 21.9 & 108 & 89 \\
\hline & Total & 0.6 & 0.9 & 1.1 & 1.2 & na & na \\
\hline \multirow[t]{2}{*}{ DTPA extraction $(\mathrm{mg} / \mathrm{kg})$} & $\mathrm{Ni}$ & 23 & 10 & 134 & 17 & na & na \\
\hline & Mn & 186 & 100 & 198 & 48 & na & na \\
\hline \multirow[t]{2}{*}{ Total extraction $(\mathrm{mg} / \mathrm{kg})$} & $\mathrm{Ni}$ & 8008 & 523 & 9251 & 1935 & 6000 & 270 \\
\hline & Mn & 6150 & 612 & 3645 & 915 & 4300 & 380 \\
\hline
\end{tabular}

'iron cap', red and yellow limonites are next, while saprolite boulders are found at the parent bedrock interface, and sometimes include garnierites (Freyssinet et al. 2005). In comparison to weathered horizons, the parent peridotite contains an average $0.3 \% \mathrm{Ni}, 30-45 \% \mathrm{MgO}$ and more than $40 \% \mathrm{SiO}_{2}$ (weight ratios). Such soils are common under tropical humid climates, e.g. in Indonesia (van der Ent et al. 2013b), SouthAmerica (Brazil, Colombia) and the Carribean (Cuba, Dominican Republic), but they also occur at higher latitudes, e.g. in Mediterranean regions (Greece, the Balkans) or in the USA (Oregon, CA) (Freyssinet et al. 2005). By 2008, world nickel production was mainly from Ni sulphides, $(788.6 \mathrm{kt}$ $\mathrm{Ni}$ ), while Ni-rich laterites only account for a third of the production at $369.1 \mathrm{kt} \mathrm{Ni}$ : This is mainly due to technical difficulty in treating lateritic Ni ores. However, Ni laterites now represent about $50 \%$ of the reserve at $31.2 \mathrm{Mt} \mathrm{Ni}$ versus 31.6 Mt for sulphide ores, and they probably represent the future of nickel supply (Mudd 2010).

Ultramafic outcrops in New Caledonia cover about $5,600 \mathrm{~km}^{2}$, i.e. $30 \%$ of the total area of the main Island. They include Ni-rich laterites, and they are currently largely exploited (Fig. 2). From 1873 until 1988, Ni production from New Caledonia solely relied on saprolitic ores (Fig. 1). These ores were treated using blast furnaces from 1910 to 1957 , while rotary kiln electric furnaces (RKEF) were introduced in 1958 and are still in use (Mudd 2010). Since 1988, limonitic ores are also treated using RKEF (Fig. 3) and represent a half of extracted ores but only $23 \%$ of Ni production. This is due to ore grades: an average $2.5 \% \mathrm{Ni}$ for saprolites versus $1.7 \%$ for limonites (DIMENC 2008). Low grades and physical properties of limonites, e.g their water-holding capacity, as well as energy costs could make hydrometallurgy more economic. Hydrometallurgical processes, aiming to extract nickel and cobalt from limonites, are currently experienced by Vale NC on the Goro deposit South of Noumea, New Caledonia. Several technical difficulties, serious delays and

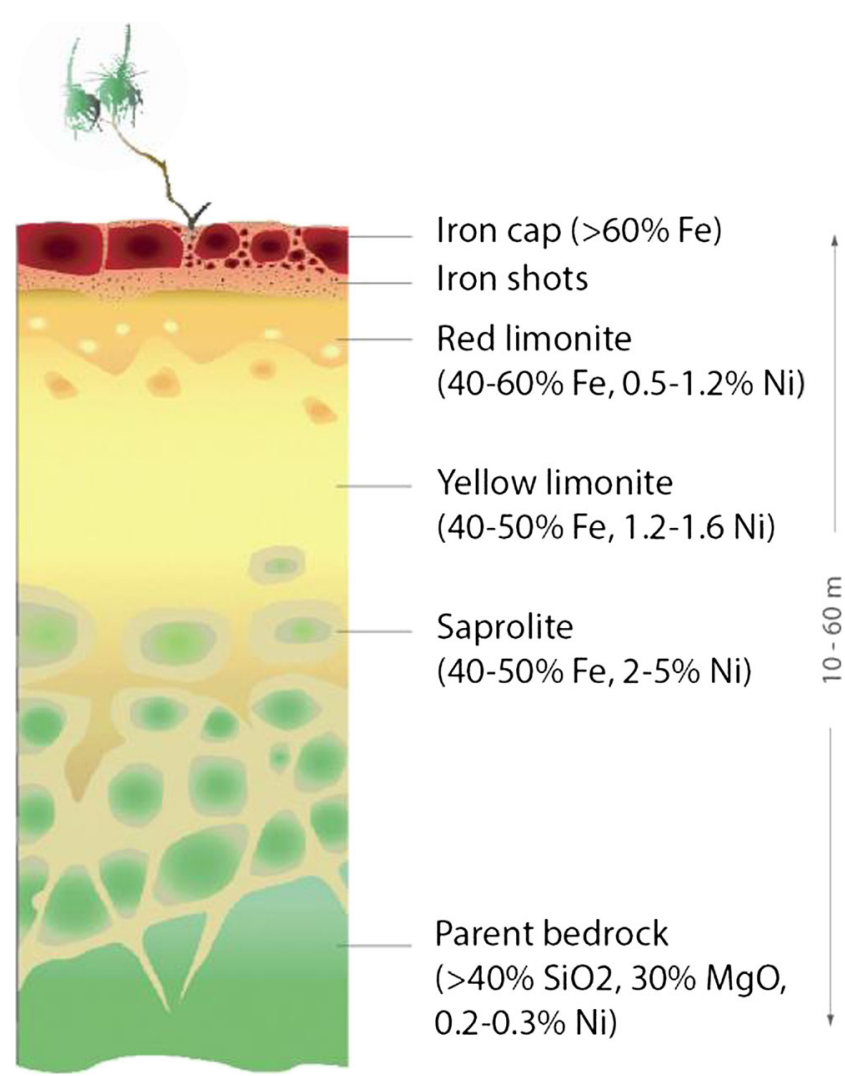

Fig. 1 Typical soil profile on ultramafic outcrops adapted from Pelletier (2006) 
Fig. 2 Ultramafic outcrops from New Caledonia and associated mining operations

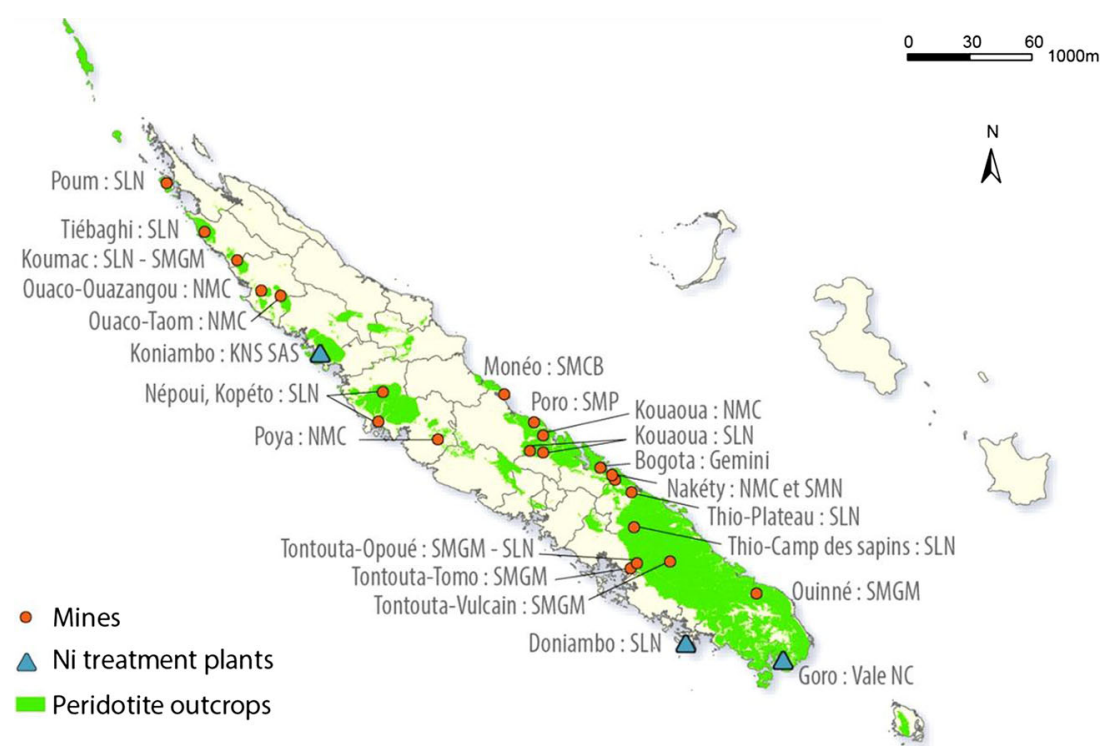

major concerns about environmental safety (Ali and Grewal 2006) emerged, but hydrometallurgy will nonetheless take a major part in the future of nickel in New Caledonia, with projects also considered by SLN (Lequesne 2014).

According to the latest estimates by the USGS, New Caledonia is currently the fifth Ni producer in the world and may account for $16 \%$ of acknowledged nickel reserves (USGS 1996-2013) and should continue to play a major role in the worldwide $\mathrm{Ni}$ industry.

\section{A major economic driver}

Current trends in global nickel production show a fairly stable increase since 1950 at an average $+4.4 \%$ per year (Mudd 2010). Reserves (according to the USGS definition) of nickel have increased lately from $40 \mathrm{Mt}$ nickel in 1999 to $70 \mathrm{Mt}$ in 2009. At the same time, reserve base increased from 140 to 150 Mt (USGS 1996-2013): This may allow production for a further 40 years at least. Major uses of nickel include stainless steel production (58\%), Ni-based alloys (14\%), casting alloys and steel (9\%), electroplating (9\%) and rechargeable batteries (5\%) (Mudd 2010). Although useful, nickel is not strategic, and prices remain low compared to other commodities such as Pt or rare earth elements, yet with a high volatility (Fig. 4). Although recycling is technically feasible, it has not developed so far: In the current economic situation, nickel supply mainly comes from primary production. Thus, demand is likely to maintain, with New Caledonia in a good position to reap the benefits.

New Caledonia's economy is essentially relying on the nickel industry: The share of nickel in the island gross domestic product (GDP) was on average $8.6 \%$ ( $\pm 3.6 \%$ ) over 1999 2008 and reached a record high above $30 \%$ in year 1968 (Fig. 4). Over the same time span, nickel exports including ores and refined products accounted for an average $93 \%$ $( \pm 3.2 \%)$ of the total value of exports from New Caledonia (Fig. 5). As appears from Fig. 4, the share of nickel in the GDP correlates with nickel prices: Over 1999-2008, $76 \%$ of the
Fig. 3 Types of ores exploited (kt ore) in New Caledonia and total nickel production $(\mathrm{kt})$

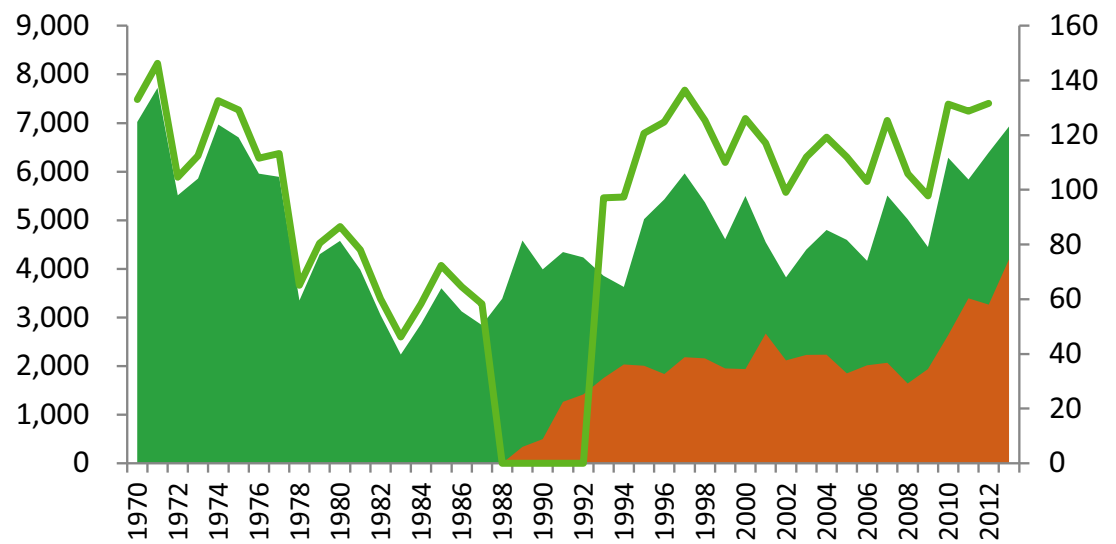

Saprolite
-Total Ni content 
Fig. 4 Share of nickel-related activities in the GDP of New Caledonia along with nickel market prices

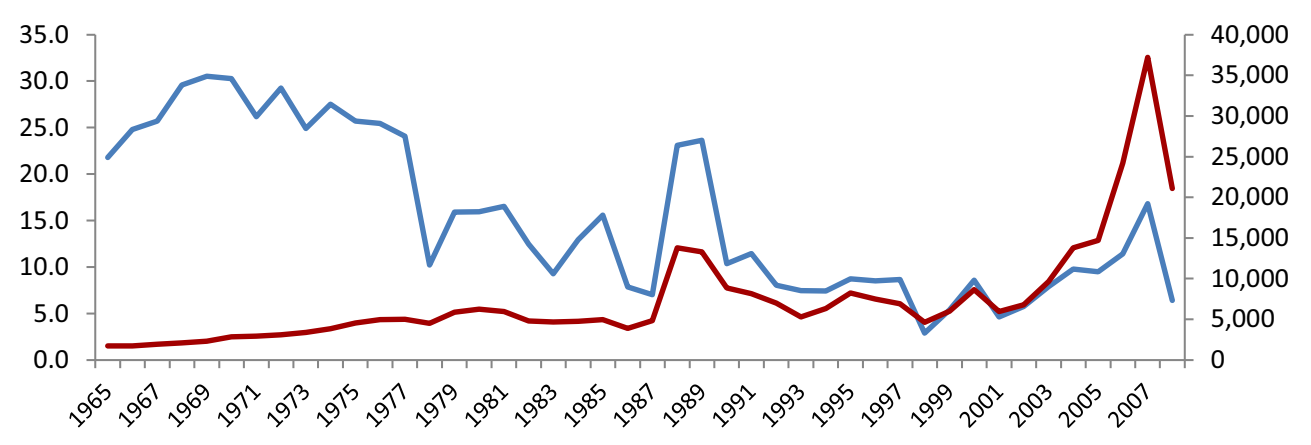

Share of Ni related activities in the GDP of New Caledonia (\%) — Ni market prices $(\$ / t)$ variance observed can be explained by nickel prices. The case of the value of nickel exports is similar with $83 \%$ of its variance explained by nickel prices. These data also show a nickel production uncorrelated with nickel prices: A main reason is that mines and smelters cannot react to price volatility. But, it also shows some sort of dependence of the New Caledonian economy on nickel, creating a possible vulnerability to variations in nickel. New Caledonia should probably diversify its sources of incomes, so as to make its economy more resilient to nickel price volatility.

However, major investments in the nickel industry recently took place in New Caledonia: SLN spent $110 \mathrm{M} €$ to improve existing ore treatment facilities, while Koniambo Nickel SAS (KNS) and Vale NC built two new plants for 2,300 M€ and 2,600 M€, respectively. Although initially planned for 2009 (Ali and Grewal 2006), first casting operations occurred in April 2013 at the KNS plant. In spite of recent financial crisis resulting in drastic decreases in nickel prices, a 3-fold increase in production capacity should result from these investments, raising it from $60,000 \mathrm{t}$ nickel per year to about 200,000 t. Negotiations are also under way to start exploration of major deposits at Creek Pernod and Prony Bay, South of Noumea. Nickel could then represent 30 to $40 \%$ of the GDP of the island (L'Huillier et al. 2010): It is clearly the major driver of the island's economy, with strong effects on country planning policy, population growth, livelihoods, ways of life and also the environment.

Environmental impacts

Environmental losses probably occurred in New Caledonia since the Melanesian discovery of the island some 3,500 years ago. Traditional agricultural practices include the use of fire to clean fields between cropping seasons and turned sclerophyll forests into niaouli savannas (Melaleuca quinquenervia, a fire-resistant species). French colonisation of the island (1854) dramatically increased losses by clearing large areas of sclerophyll forests for cattle grazing mainly. By now, sclerophyll forests only cover $2 \%$ of their original area and represent a conservation challenge (Bouchet et al. 1995; Gillespie and Jaffre 2003). Introduction of alien animals such as cats, rats, dogs or the Indonesian deer (Cervus timorensis) also proved detrimental: Large deer populations exert strong grazing pressures, thus preventing the recovery of forests, while birds such as the flagship species Kagu (Rhynocetos jubatus) are threatened by cats, rats and dogs (Mittermeier et al. 1996; Robinet et al. 1998). In the case of alien plants, they may become invasive in savannas and outside ultramafic outcrops in general, but extreme edaphic conditions on ultramafic outcrops make them of lesser concern in this
Fig. 5 Share of nickel exports from New Caledonia along with nickel market prices

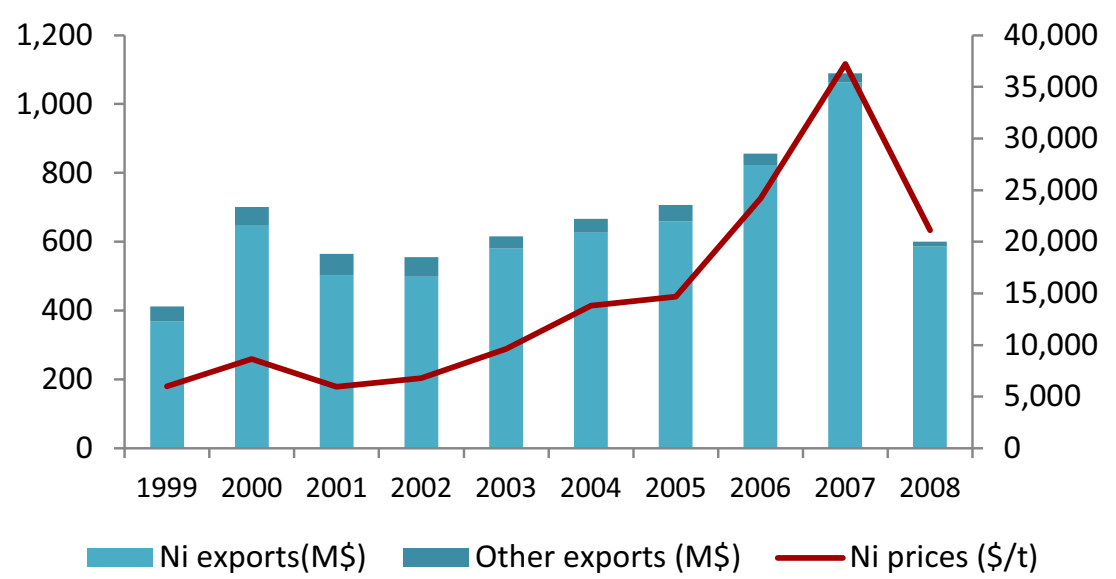


environment (Meyer et al. 2006). Although sclerophyll forests are probably the most impacted and endangered terrestrial ecosystem from New Caledonia, mining is also recognised as a potential threat (Dugain 1953; Jaffré et al. 1977) with mining-related environmental issues still high on the agenda (Jaffre et al. 2010; L'Huillier et al. 2010; Pascal et al. 2008; Wulff et al. 2013).

In the beginning, mining operations were mainly carried underground following high-grade lodes (up to $15 \% \mathrm{Ni}$ in garnierites). Open cast mining appeared around 1920 as a result of decreasing ore grades $(5 \% \mathrm{Ni}$, weight ratio): Before ores can be accessed, vegetation cover, topsoil and low-grade limonites are removed, thus exposing bare ground (Fig. 6). However, it remained limited to small exploitations relying on human forces mainly. Mechanisation occurred after World War II and allowed the exploitation of ores with continuously decreasing $\mathrm{Ni}$ content, about $1.7 \% \mathrm{Ni}$ in limonites and $2.5 \%$ in saprolites (DIMENC 2008). From 1950 to 1975 , mining was conducted recklessly, with high environmental impacts: Low-grade limonites and rocks were usually pushed down the slopes and ended up in thalwegs. Decreasing ore grades also increased the quantity of spoils (non-refined waste from open cast mining) and tailings (waste from ore processing) that have to be treated: Current trends are at $3.5 \mathrm{t}$ spoils moved to access $1 \mathrm{t}$ ore (Table 2).

Resulting perturbations on water flows and dramatic soil erosion (Bird et al. 1984; Dupon 1986; Latham 1971) cause metal-rich sediment transport downstream into rivers and the lagoon (Ambatsian et al. 1997; Fernandez et al. 2006; Migon et al. 2007; Ouillon et al. 2010), with possible bioaccumulation (Bustamante et al. 2000; Hedouin et al. 2007), and potential toxicity to marine organisms (Florence et al. 1994). In some cases, fertile areas along river banks were lost, due to continuing sedimentation of metal-rich sediments (Danloux and Laganier 1991; Dupon 1986; Jaffré et al. 1977), which may cause phytotoxicity or accumulation in cultivated plants (L'Huillier and Edighoffer 1996). In 1975, new techniques were set up by SLN to limit environmental impacts (Jaffré and Pelletier 1992). These are now generally considered as good practice guidance and include the following:

1. Replacement of crawler dozers by excavators and dump trucks,

2. On site storage of mine spoils using stable and welldrained piles (Fig. 7),

3. Bunds protecting track sides and limiting excavation areas,

4. Effective control of water flows on mines, so as to reduce terrigenous inputs into water streams and the lagoon.

International environmental standards are also being enforced, with SLN expecting to comply with ISO 14001 by 2014 .

However, economic constraints usually prevail, and spoils or tailing storage still happens in thalwegs, where remnant forests may stand (Jaffre et al. 2010). This issue is only to become more acute with the exploitation of lower grade ores, such as limonites. It will result in continuing habitat loss and fragmentation and erosion of the local biodiversity. According to Jaffré et al. (2010), the best practice could be to store mining waste only where severe degradation already occurred, typically old mines. In spite of a general agreement that prevention of further damage is the priority, 20,000 ha of degraded land still needs crucial rehabilitation (DIMENC 2008). The ecological restoration (as defined by the Society for Ecological Restoration (2004)) of ecosystems affected by mining is considered (L'Huillier et al. 2010) but still needs further development. Mine rehabilitation combined with economic uses of
Fig. 6 Impacts of mining as seen at the 'Camp des Sapins' mine, Thio, New Caledonia

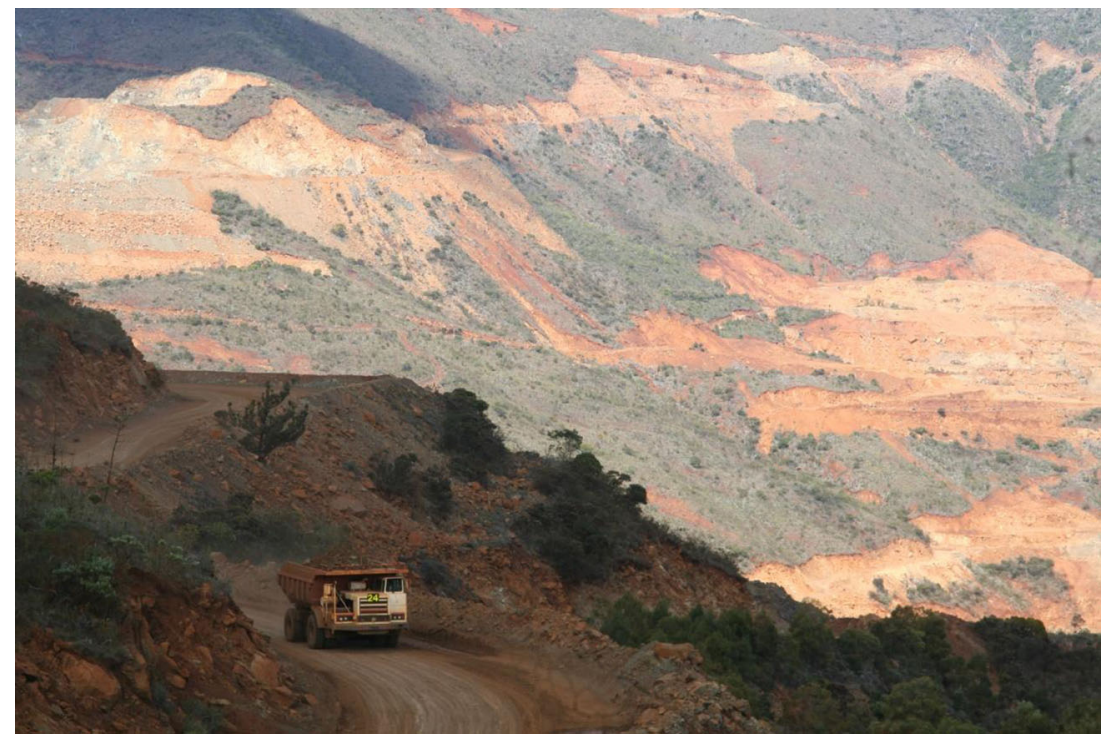


Table 2 Estimation of the quantity of ore extracted from New Caledonia and the resulting spoil production (DIMENC 2008)

\begin{tabular}{llll}
\hline Time span & Extracted ore $(\mathrm{t})$ & Ratio spoil/ore & Spoil $(\mathrm{t})$ \\
\hline Before 1920 & 3048549 & 1,0 & 3048549 \\
$1921-1950$ & 5003762 & 1,5 & 7505643 \\
$1951-1975$ & 78356696 & 2,0 & 156713392 \\
$1976-2001$ & 133118259 & 3,5 & 465913907 \\
\hline
\end{tabular}

the local biodiversity provides interesting perspectives, e.g. recycling of metal hyperaccumulating plants through a new chemical concept, termed 'Ecocatalysis', which represents an extraordinary environmental opportunity. The concept is based on a novel but very important market in 'Green Chemistry', which is 'Lewis acid' catalysts used in organic synthesis. This type of catalysis is one of the most powerful tools to obtain chemical transformations with low environmental impacts (Escande et al. 2013; Escande et al. 2014a, b; Grison et al. 2014; Grison and Escande 2013a, b, c; Grison and Escarre 2011a, b; Losfeld et al. 2012a, b, c; Thillier et al. 2013).

\section{Opportunities for the restoration of mining-impacted ecosystems}

Reclamation, phytoremediation or ecological restoration?

In conjunction with current efforts to make mining less harmful, it is also crucial to address the challenging task of reclaiming the ecosystems affected by mining. A general reflection has been conducted on this aspect but was mainly based on experiences from Western Europe, especially the UK (Bradshaw 1997; Bradshaw 1992; Tordoff et al. 2000). Developing countries are nonetheless catching up, with various experiences reported (Fitamo and Leta 2010; Kamran et al. 2014; Lum et al. 2014; van der Ent et al. 2013b), particularly from China (Shu et al. 2005; Wong 2003; Ye et al. 2000). Past experiences may provide a general framework to plan and assess reclamation schemes and may be useful for New Caledonia. The main aims identified are the following:

1. prevent soil erosion by water or wind,

2. limit the dispersion of metal-rich particles,

3. and restore the aesthetical value of impacted landscapes.

Such aims can be achieved by the development of a perennial vegetation cover: This approach is deemed cost-effective and boasted better public acceptance (Bradshaw 1997). Limiting factors then fall into three categories:

1. Physical, e.g. poor soil structure resulting in low waterholding capacity,

2. Nutritional, as mine spoils and tailings are often deficient in essential macronutrients,

3. And toxicity, as residual concentrations of metals may hinder the development of a viable vegetation.

Moreover, although successful reclamation was achieved at specific sites, there is no generally applicable technology, mainly because of large variations in physical, chemical and biological factors, as well as climate (Tordoff et al. 2000). In line with Bradshaw (1997b), it is also necessary to distinguish between simple reclamation and restoration. Both share the aims and issues stated previously, but

1. Reclamation only requires the achievement of an appropriate ecosystem, which may have different structure and functions compared to the original ecosystem (i.e. before mining).

2. Restoration on the other hand requires both structure and functions of the original ecosystem to be achieved.

Taking the unique and original flora of New Caledonia into account, restoration appears as the most desirable possibility.

The concept of phytoremediation emerged in 1993 as a unifying approach to the use of plants to tackle soil contamination issues, including mining-related metal contamination (Cunningham and Berti 1993). Research efforts were mostly focussed on two approaches:

Fig. 7 Typical storage of mine spoils

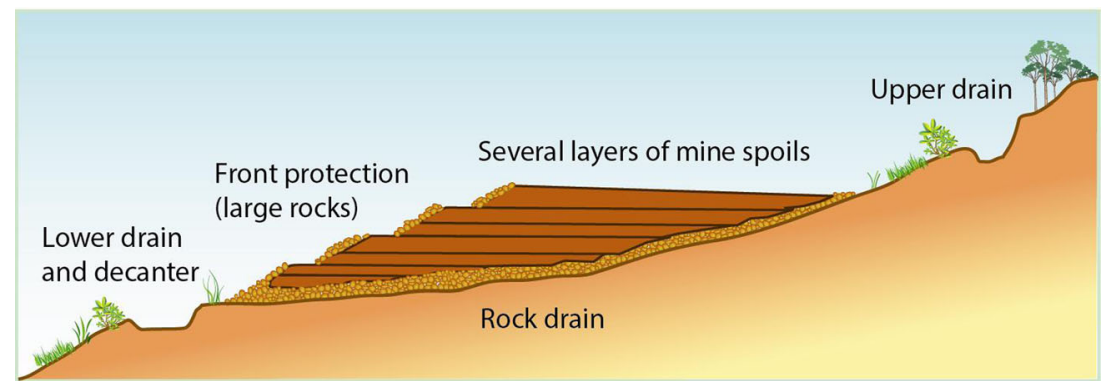


1. phytostabilisation, where the development of sustainable vegetation should prevent contaminant mobilisation

2. and phytoextraction, where plants are used as bio-pumps to extract contaminants.

Subject to much debate in the literature for its possibly too broad scope and confusing terminology (Conesa et al. 2012; Ernst 2000), phytoremediation is not fully relevant to address mining impacts where lateritic ores are exploited. In the case of New Caledonia, main reasons for that can be the following:

1. Unharmed or less harmed ecosystems can usually be found nearby mines and may provide a reference for restoration. Such ecosystems are recognised for their high endemism and have patrimonial value (Bradshaw 1997b; Jaffré 1980; Whiting et al. 2004)

2. The vegetation naturally occurring on ultramafic outcrops from New Caledonia is already adapted to some of the edaphic constraints found on nickel mines or mining waste, high $\mathrm{Mg}$ and low $\mathrm{P}$ for instance (Table 1). Additional constraints related to mining impacts, e.g. compaction, heterogeneity, poor soil structure, lack of organic matter and low water-holding capacity, nonetheless exist, but the local and often endemic vegetation can provide suitable candidates for mine site restoration (Jaffré and Pelletier 1992).

3. Ferritic ferralsols found on ultramafic outcrops from New Caledonia are naturally rich in nickel as well as other potentially toxic metals such as $\mathrm{Co}$ or $\mathrm{Cr}$ (see Table 1), and they are not suitable for agriculture. Therefore, mines cannot be considered as contaminated land. Removal of the metals through phytoextraction is not necessary.

A detailed comparison of the respective cases of nickel mines from New Caledonia (lateritic ores) and Canada (Sudbury, sulphide ores) was made by Bradshaw (1997b): Different impacts can be related to mining practices (open cast in New Caledonia, below ground in Canada), ores chemistry and ore enrichment needs. Such parameters and the local environment need to be thoroughly understood to determine where phytoremediation can be useful, e.g. in Canada and where restoration may be more desirable, e.g. in New Caledonia. A critical look at the literature also shows that phytostabilisation is very similar to reclamation as defined by Bradshaw (1997b) and probably overemphasises the role of the vegetation cover in mine site reclamation. Although useful, vegetation cannot be the sole tool to achieve mine reclamation (Robinson et al. 2009).

Lately, the concept of ecological restoration emerged (SER 2004), along with the idea of natural capital (Clewell and Aronson 2006): It is in line with recommendations by Bradshaw (1997b) and represents the most relevant approach for New Caledonia. Ecosystem services such as the regulation of water flows or the control of soil erosion are obviously provided by a sustainable plant cover, but ecosystems from New Caledonia also have a patrimonial value: They provide fundamental insights on the evolution of plants (Amborella Genome Project 2013) but also valuable molecules with pharmaceutical properties (Allard et al. 2011; Allard et al. 2012). Nickel hyperaccumulating plant species were also discovered for the first time in New Caledonia (Jaffre et al. 1976), and they are particularly abundant there, along with manganese hyperaccumulators and accumulators (Fernando et al. 2013; Jaffré 1980; Jaffre et al. 2013). Such species provide material for the fundamental understanding of metal hyperaccumulation (Jaffre et al. 2013; Merlot et al. 2014); they may serve as a starting material for innovative applications (Escande et al. 2014a; Grison and Escande 2012; Losfeld et al. 2012b). Thus, ecological restoration of New Caledonian ecosystems affected by mining appears as the most comprehensive objective, since 2009 required by law to plan mine rehabilitation in New Caledonia and good practice guidance issued by local scientists advocates for ecological restoration (L'Huillier et al. 2010).

\section{Past and ongoing experiences from New Caledonia}

Selection of metal-tolerant species for mine reclamation or restoration was performed in the UK as early as 1979 (Smith and Bradshaw 1979) but was still not on the go for tropical ecosystems by 2000 (Tordoff et al. 2000). However, there is probably a flaw in reporting experiences, with an extensive literature available in French on mine restoration in New Caledonia (Jaffré et al. 1994; L'Huillier et al. 2010). As appears from the literature, New Caledonia is probably the leader in the restoration of tropical ecosystems impacted by mining. This is due to early realisation of dramatic soil erosion (Dugain 1953) and acute awareness of the value (on various grounds) of the local biodiversity (Myers 1988).

First field experiments to investigate the possibility of mine revegetation started in 1971 in New Caledonia under the direction of the 'Centre Technique Forestier Tropical' (CTFT) at the request of the AMAX company. These experiments conducted in the south of Grande Terre were followed by many others on different mining lands during 10 years, at the request of the mining company SLN, under the supervision of the CTFT or the 'Office de la Recherche Scientifique et Technique d'Outre-Mer' (ORSTOM). The aims of the first experiments were clearly not to achieve the ecological restoration of the areas impacted by mining but merely to control soil erosion and restore some aesthetical value to the impacted landscapes. During this period, the response of many exotic and native species was investigated on various soil types including limonites, mine spoils and tailings, at different altitudes, with different plantation densities, soil preparation and fertilising treatments. A comprehensive report of these 
experiments was issued in 1990 after at least 9-year follow-up (Cherrier 1990). The following conclusions could be drawn:

1. any type of soil decompaction before plantation is useful,

2. mulching is a useful way to retain soil humidity,

3. and the use of topsoil and fertilisers always significantly improves plant response.

The above recommendations are still in use now. As regard to species selection, two species gave the best results in terms of their survival and growth: a native legume, Acacia spirorbis, and an endemic Casuarinaceae, Casuarina collina, which is morphologically and ecologically very similar to the invasive species Casuarina cunninghamiana. Because of their gregarious behaviour, these species tend to form monospecific populations and hinder further ecological succession. They are even considered invasive in different conditions of soils and altitude (Meyer et al. 2006). Thus, the widespread use of these sole species has been deprecated (Jaffré et al. 1997; L'Huillier et al. 2010). Introduced legumes and grasses were not successful.

First consideration of restoration rather than mere reclamation appeared in 1989, concretised by several agreements between ORSTOM (now IRD) and SLN, and also by experiments involving CTFT (which became CIRAD Forêt and now IAC), the Southern Province and mining companies. Research has focussed on selecting a set of native pioneer species, herbaceous and shrubby, likely to initiate the phenomenon of secondary succession. These studies led to the selection of around 60 species including Cyperaceae (Machaerina (ex. Baumea) deplanchei, Schoenus juvenis, Schoenus neocaledonicus, Costularia comosa and Lepidosperma perteres), nitrogen-fixing species such as Serianthes calycina (Fabaceae) or species of the Gymnostoma genus (Casuarinaceae), and various species of the 'maquis minier' such as the following: Grevillea spp (Proteaceae), Carpolepis laurifolia, Tristaniopsis guillainii (Myrtaceae), Oxera neriifolia (Lamiaceae). Collaboration of SLN, ORSTOM and local research institutes resulted in the publication of a book (Jaffré and Pelletier 1992), with detailed data on about 60 pioneering species usually observed to grow on areas impacted by mining. The publication of such a book made valuable data available and probably spurred the development of commercial tree nurseries to ensure mine reclamation: It was a major step towards the ecological restoration of mining-impacted ecosystems from New Caledonia.

However, seed collection appeared difficult, and the quantity of available seeds was limited. Successful plantation from cuttings was also achieved for various species, but this approach is now less considered as it does not maintain genetic diversity. The perspective of using hydroseeding was also raised as it clearly appeared as a cost-effective option only limited by seed availability. Since 2000 , research continues and now focusses on improving the knowledge on seed ecology, dormancy, germination and seed conservation (Wulff et al. 2012b), on genetic diversity (Wulff et al. 2012a) and structures of plants and associated microorganism communities (Amir et al. 2008; Amir et al. 2007). An improved understanding of the interactions between plants, fauna and microorganisms was achieved: Cyperaceae were particularly investigated for the possibility to produce large quantities of seeds (Lagrange 2009), an improved knowledge of rhizobia associated with Serianthes calycina (Chaintreuil et al. 2007; Hery et al. 2005) and frankia associated with Casuarinacea (Gauthier et al. 1999; Navarro et al. 1999) and mycorrhizal associations (Jourand et al. 2014; Lagrange et al. 2013). This allows improving germination performance, the management of topsoil, taking into account the importance of mycorrhizae in the establishment of plants, recommending a set of plants increasingly diversified and adapted to different environmental conditions. Multiple collaborations resulted in the publication of a collective reference book (L'Huillier et al. 2010), which assesses the knowledge acquired over 40 years on mining environments in New Caledonia, makes recommendations on best available practices in ecological restoration and gives practical information on the use of about a hundred plant species.

Potential for the economical exploitation of $\mathrm{Ni}$ and $\mathrm{Mn}$ hyperaccumulators from New Caledonia

\section{Phytoremediation by way of phytoextraction and phytomining}

Two approaches to the commercial use of metal hyperaccumulators have been widely investigated:

1. Phytoremediation by way of phytoextraction, often referred to as phytoextraction, addresses the issue of metal-contaminated soil and aims to provide a costeffective way to clean them.

2. Phytomining, initially termed 'biomining' (Cunningham and Berti 1993), refers to the use of plants, usually metal hyperaccumulators, to produce bio-ores subsequently used in metal production (Brooks et al. 1998).

However, the design of both approaches is probably not fully relevant with the aims stated.

A major limitation of metal removal by phytoextraction remains: No relevant uses for the contaminated biomass have been found (Ernst 2000; Sas-Nowosielska et al. 2004). Current reflection in the scientific community suggests finding alternative uses for sites contaminated with metals such as closed mines (Conesa et al. 2012; Ernst 2005). According to Conesa et al. (2012), 'The commercial success of phytotechnologies depends on the generation of valuable 
biomass on contaminated land, rather than a pure remediation technique that may not compare favourably with the costsof inaction or alternative technologies'. However, it was previously emphasised that such options are not relevant for New Caledonia, where fast growing high-biomass species usually considered are not available (Grison et al. 2013; Losfeld et al. 2012b) and where introduction of alien species could be undesirable, illegal and probably unproductive (L'Huillier and Edighoffer 1996; L'Huillier et al. 2010).

Phytomining, initially termed biomining (1993), was thought of as a potential outlet for the metal-contaminated biomass produced in phytoremediation by way of phytoextraction: In this case, the biomass should be considered as metal-rich rather than contaminated. However, phytomining now generally refers to the use of plants, usually metal hyperaccumulators, to recover valuable elements from low-grade ores and not from contaminated soil (Brooks et al. 1998). As nickel hyperaccumulating species are most common, phytomining for $\mathrm{Ni}$ was considered to have the greatest potential. Au phytomining was also considered (Anderson et al. 1998); although technically more difficult (WilsonCorral et al. 2012), it is motivated by Au prices 2,500 times higher than $\mathrm{Ni}$.

Phytomining was developed for $\mathrm{Ni}$ to an industrial level using Alyssum species grown in Oregon, USA. Nickel recovery from the biomass was performed by treating plant ashes in pyrometallurgical units (Chaney et al. 2007). Other trials are currently underway, using chemical separation techniques (Barbaroux et al. 2012), with biomass supply originating from Albania (Bani et al. 2007). Although metallophyte biodiversity hots pots are located in tropical areas, e.g. Cuba or New Caledonia (van der Ent et al. 2013a), there are few reports of phytomining experiments in tropical areas, and it was not expected to have the greatest potential (Reeves 2003). First experiments in tropical Ni phytomining were reported by van der Ent et al. (2013b). In spite of the renown of its metallophyte biodiversity, phytomining was never considered in New Caledonia until recently (Losfeld et al. 2012b). Interesting lessons can be drawn from other experiences:

1. Focussing on the local biodiversity may avoid poor results, as reported using Alyssum species in Indonesia (Anderson 2013; van der Ent et al. 2013b).

2. It may also avoid the emergence of invasive species as was the case for Alyssum species in the USA (Oregon Department of Agriculture 2014).

3. It is a way to promote the conservation of metallophyte species (Whiting et al. 2004).

Considered unrealistic in first instance (Baker et al. 1988), phytomining is not reported to have met the expected commercial success. In the case of nickel, current turmoil in the industry due to low prices is not likely to make $\mathrm{Ni}$ phytomining profitable.

\section{The emergence of Ecocatalysis as a tool for Green Chemistry}

New applications for metal-rich biomass emerged in late 2009 in the field of Green Chemistry (Grison and Escarre 2011a; Grison and Escarre 2011b). Plant species able to hyperaccumulate transition metals, e.g. $\mathrm{Ni}^{2+}$ and $\mathrm{Mn}^{2+}$, can be directly used as green reagents and catalysts in organic fine chemical reactions (Grison et al. 2014; Grison and Escande 2013a, b, c; Grison and Escarre 2011a, b; Losfeld et al. 2012b, c; Thillier et al. 2013). This original approach brings the first perspective of enhancing the unique metal-rich biomass and establishes a new field of Green Chemistry: Ecocatalysis. The first results show that polymetallic ecocatalysts could present performances and selectivity largely higher than classical homogenous and heterogeneous catalysts. The concept of Ecocatalysis is no longer a simple recovery of phytoremediation technologies. Ecocatalysts are original (unusual oxydation states, new associated chemical species) and effective, and they offer a unique opportunity of cooperative catalysis with the huge potential synergetic activity of plant elemental composition. Their activities, chemo- and stereoselectivity and recyclability are higher than classical catalysts in various reactions (Escande et al. 2013; Escande et al. 2014a, b; Grison et al. 2014; Grison and Escande 2013a, b, c; Grison and Escarre 2011a, b; Losfeld et al. 2012c). These results encourage a new approach to metal phytomining: It is now recognised as an alternative source of metals for Green Chemistry (Hunt et al. 2014), and various teams are now looking into Ecocatalysis (Parker et al. 2014). The general pathway from zinc, nickel, copper, palladium, manganese-rich plants to ecocatalysts, exemplified for manganese accumulator Grevillea exul (Fig. 8), starts with the collection of metalrich leaves. The leaves are thermally treated $\left(550{ }^{\circ} \mathrm{C}\right.$ max), which releases water and destroys organic matter. Metal-rich ashes obtained are treated with diluted acids, e.g. hydrochloric acid to produce polymetallic Lewis acids. Under optimised conditions, the ecocatalyst was dispersed on montmorillonite K10. Composition of the solid finally obtained is original and results in higher catalytic activities compared to pure Lewis acids that are commercially available, e.g. $\mathrm{ZnCl}_{2}$ or $\mathrm{NiCl}_{2}$ (Escande et al. 2014a, Grison et al. 2013).

Example application using Grevillea exul leaves to catalyse the Biginelli reaction

The original composition of Eco-Mn derived from G. exul prompted to us to investigate how this mixture could initiate Lewis acid-catalysed reactions. We wish to give an illustrative example, which culminated in a three-component reaction, the Biginelli reaction leading to dihydropyrimidinones, described 
Fig. 8 Key steps to produce solid catalysts from Mn-rich biomass (Grevillea exul)

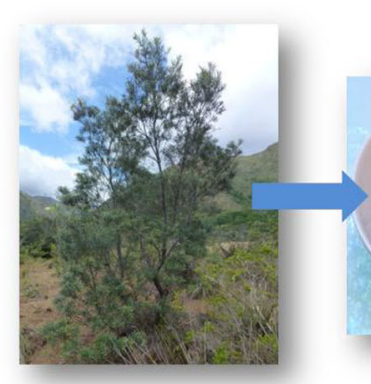

Wild Grevillea exul

from

New Caledonia
Ashes obtained

from Grevillea exul leaves after

thermal treatment at $550^{\circ} \mathrm{C}$

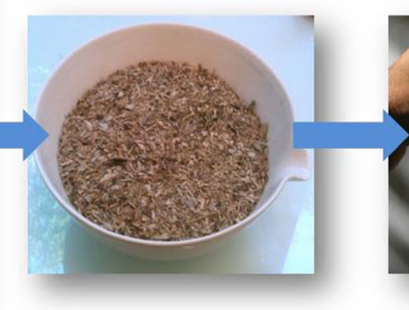

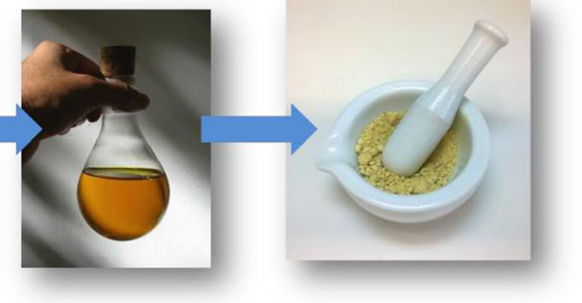

Acid digestion digestion of the ashes (e.g. $\mathrm{HCl}, 70^{\circ} \mathrm{C}, 3 \mathrm{~h}$ )
Eco-Mn that can be used as catalyst in organic syntheses in full details by Grison et al. (2013) and Escande et al. (2014a) with Eco-Zn and Eco-Ni. The chemical reaction can be catalysed by $\mathrm{Ni}$ hyperaccumulators, e.g. Psychotria douarrei and Geissois pruinosa, as well as $\mathrm{Zn}$ hyperaccumulators, e.g. Noccaea caerulescens. We describe here the first utilisation of Eco-Mn, the ecocatalyst derived from $G$. exul as an example species (useful for the phytoextraction in New Caledonia) in this multi-component reaction. The Biginelli reaction provides access to molecules with interesting pharmacological properties (Kappe 2000) including monastrol, a famous mitosis inhibitor (Mayer et al. 1999). Using ecological catalysts derived from New Caledonian species allows the synthesis of known dihydropyrimidinones with improved yields but also allows access to unknown dihydropyrimidinones with potentially new interesting pharmacological properties (Escande et al. 2014a; Grison et al. 2013). The supported catalyst, the two substrates and the reagent were mixed thoroughly and stirred at $80{ }^{\circ} \mathrm{C}$ under solvent-free conditions for $12 \mathrm{~h}$. According to our proposal, Eco-Mn promoted the reaction between benzaldehyde, ethyl 3-ketopentanoate and urea in a one-pot protocol. After recrystallisation, the pure expected heterocycle (ethyl 6methyl-4-phenyl-2-oxo-1,2,3,4-tetrahydropyrimidine-5-carboxylate (monastrol)) was obtained with a high yield $(88 \%)$ (Fig. 9).

Typical yield for manganese accumulator $G$. exul in natural conditions is $2-\mathrm{kg}$ dry biomass per individual at $4,000 \mathrm{mg}$ manganese per kg dry leaves. Plantation densities up to 2,500 individual par hectare are possible, which would lead to potential yields of $20 \mathrm{~kg}$ manganese per hectare per harvest. This allows the production of $213-\mathrm{kg}$ manganese-rich catalyst at $9.4 \%$ manganese per cultivated hectare. The use of $213-\mathrm{kg}$ catalyst in one Biginelli reaction (Table 3 ) could produce $415 \mathrm{~kg}$ of the dihydropyrmidinone of interest. The process allows Eco-Mn recycling without significant loss of activity: A second cycle resulted in $830-\mathrm{kg}$ product. The ecocatalyst led to higher yield in greener conditions than commercial Lewis acids. It must be noticed that the added value is generated from selling the chemical product finally obtained, which decorrelates incomes from metal prices. Thus, mine reclamation combined with economic profits has some potential in New Caledonia, an interesting option to support reclamation as well as ecological restoration.

\section{Conclusion}

At present, the economy of New Caledonia is largely supported by nickel production and ore exports: The archipelago is currently the fifth world producer of this metal and may account for some $16 \%$ of acknowledged reserves. Thus, future economic development is also likely to rely on further exploitation of nickel. Yet, New Caledonia is also recognised for its remarkable biodiversity, the flora on ultramafic substrates being a major component of this biodiversity. Nickelrich laterites, locally known as terrains miniers, host a particularly original flora, including various species with the ability to accumulate nickel or manganese.

Fig. 9 Synthesis of a pyrimidinone (Biginelli reaction)<smiles>CCOC(=O)CC(=O)[18F]</smiles><smiles>CCOC(=O)C1=C(C)NC(=O)NC1c1ccccc1</smiles> 
Table 3 Stoichiometry and yields of an example of the Biginelli reaction

\begin{tabular}{lllll}
\hline Reagents & 1 & 2 & 3 & Catalyst \\
\hline- & Urea & Ethyl acetoacetate & Benzaldehyde & $\begin{array}{l}\text { Mn from Grevillea exul } \\
\text { Eco-Mn@9 wt\% Mn }\end{array}$ \\
Stoichiometry & 1 & 2 & 2 & 0.2 \\
\hline
\end{tabular}

Mining for nickel started some 140 years ago in New Caledonia, with significant production increases in the last decade. As a result, fires and mining are now the major threats to the terrestrial biodiversity of the archipelago. In an attempt to reduce the impacts of nickel exploitation, mining companies have progressively developed new practices for prospection, mine layouts and the management of mining effluents. However, mining is still open cut, and with decreasing ore grades, large surface areas will be stripped, and large volumes of soil disturbed. Because of the value of the local and often endemic flora, as impacts cannot be fully circumvented, restoration of the mining environment has to be considered.

Research on these aspects is led by various institutes and was often funded by mining companies themselves. It increased the understanding of the mining environment and allowed the selection of species suitable for restoration, with the ability to withstand poor edaphic conditions. First experiments focussed on exotic species, or local species with gregarious or even invasive behaviours. The results obtained remained far from the expectations of ecological restoration.

Further experiments aimed at using native pioneer species along with species with the ability to improve soil properties. Long-term studies allowed the selection of species that were able to withstand different types of land degraded by mining. Understanding phenology at the specific level and organising seed collection were also decisive: It allowed the creation of nurseries and made hydraulic seeding potentially available. By now, there are still various studies currently in progress, with the following priorities:

1. improve the performance of species presenting nitrogenfixing or mycorhizal (endo or ecto) symbioses,

2. develop efficient seed collection, their germination and conservation, and also investigate seed production,

3. improve the understanding of topsoil recycling, so as to develop good practice guidance for mining operators.

Field experiments using local species adapted to the ultramafic substrates confirmed the interest of the 'ecological restoration' approach. Yet, the results remain heterogeneous, and in addition to understanding plant responses, site-specific approaches are necessary due to high variability in soil chemical and physical properties, as well as climatic condition. Such constraints plus the lack of organisation in seed collection (and production) entail high restoration costs, without a guarantee for long-term success. Thus, it is still difficult to provide turnkey restoration solutions for mining companies.

The approach to the restoration of mining areas is currently at a crossroads, with a possible diversification of the stated aims. While the current option is to focus on single exploitation areas without proper conservation plans, massifs appear as the right ecological unit to plan conservation and restoration. Most representative and significant scrublands in each massif should be totally preserved, along with all residual forests in thalwegs. Avoiding destruction of these areas, and even promoting their extension, could be a way to maintain their ecological diversity and functions without excessive costs. This seems more feasible in the short run than ambitious and costly ecological restoration of severely harmed ecosystems. In such an approach, it would be possible to focus restoration efforts on the first step of the ecological succession, where a restricted number of species known to improve soil and growing conditions could be used.

Metallophyte species, including metal hyperaccumulators, also have some interest: Various species proved useful for mine restoration (Geissois spp.,Grevillea spp., Phyllanthus spp.) and the development of new outlets, e.g. ecological catalysts could provide revenues. Developing reclamation schemes for highly degraded quarries or spoil storage areas using metal hyperaccumulators along with Cyperaceae and other soil-improving species could provide an efficient way to control soil erosion and water flows on degraded land. Generating alternative incomes through the valuation of metal-rich biomass used in organic chemistry could cover the cost of the operation but also generate alternative economic activities for the country.

Such prospects, built with the idea of managing biodiversity at a larger scale, taking the specificities of each massif into account, could lead to an improved conservation of the unique and original metallophyte and ultramafic flora of New Caledonia. Economic use of nickel and manganese 
hyperaccumulators opens new perspectives for the restoration of mining-impacted ecosystems, for the economy of New Caledonia, but also for scientific research as it raises new questions on metal hyperaccumulation. The new concept of Ecocatalysis can be the starting point of a novel plant-inspired metallo-catalytic platform for the synthesis of biologically interesting molecules and should spur the development of phytoextraction. The approach can be extended to access to numerous molecules with high added value (e.g. aromatic heterocycle scaffolds, building blocks for chemical industries and numerous molecules of biological and medicinal interest). The development of this new concept can create a paradigm shift in sustainable and green chemistry: Phytoextraction can become new efficient catalytic systems.

Ecological restoration or rehabilitation of sites with large reserves of transition metals, but also high nature conservation value, e.g. in New Caledonia, can be accelerated by these new phytotechnologies, and partly financed by the ecocatalysts produced in the recycling process of biomass. This activity should enable to develop a new green circular economy.

Acknowledgments The authors warmly thank Marion Anquez (IAC) for providing the picture used as Fig. 6. Financial support from the 'Agence Nationale pour la Recherche' (ANR 11ECOT01101), Société Le Nickel (SLN), and Ecole Polytechnique, Paris Tech (PhD studentship) is also gratefully acknowledged.

\section{References}

Alexander EB (2009) Soil and vegetation differences from peridotite to serpentinite. Northeast Nat 16:178-192

Ali SH, Grewal AS (2006) The ecology and economy of indigenous resistance: divergent perspectives on mining in New Caledonia. Contemp Pac 18:361-392

Allard P-M et al (2011) Alkylated flavanones from the bark of Cryptocarya chartacea as dengue virus NS5 polymerase inhibitors. J Nat Prod 74:2446-2453

Allard P-M et al (2012) Antiviral chlorinated daphnane diterpenoid orthoesters from the bark and wood of Trigonostemon cherrieri. Phytochemistry 84:160-168. doi:10.1016/j.phytochem.2012.07. 023

Ambatsian P, Fernex F, Bernat M, Parron C, Lecolle J (1997) High metal inputs to closed seas: the New Caledonian lagoon. J Geochem Explor 59:59-74. doi:10.1016/s0375-6742(96)00020-9

Amborella Genome Project (2013) The Amborella genome and the evolution of flowering plants. Science 342:1456-1457. doi:10. 1126/science. 1241089

Amir H, Perrier N, Rigault F, Jaffre T (2007) Relationships between Nihyperaccumulation and mycorrhizal status of different endemic plant species from New Caledonian ultramafic soils. Plant Soil 293:23-35. doi:10.1007/s11104-007-9238-0

Amir H, Jasper DA, Abbott LK (2008) Tolerance and induction of tolerance to $\mathrm{Ni}$ of arbuscular mycorrhizal fungi from New Caledonian ultramafic soils. Mycorrhiza 19:1-6. doi:10.1007/ s00572-008-0197-y

Anderson CWN (2013) Hyperaccumulation by plants. In: Hunt A (ed) Element Recovery and Sustainability. The Royal Society of Chemistry, pp 114-139. doi:10.1039/9781849737340-00114.
Anderson CWN, Brooks RR, Stewart RB, Simcock R (1998) Harvesting a crop of gold in plants. Nature 395:553-554. doi:10.1038/26875

Baker A, Brooks R, Reeves R (1988) Growing for gold... and copper... and zinc. New Sci 116:44-48

Bani A, Echevarria G, Sulce S, Morel JL, Mullai A (2007) In-situ phytoextraction of $\mathrm{Ni}$ by a native population of Alyssum murale on an ultramafic site (Albania). Plant Soil 293:79-89. doi:10.1007/ s11104-007-9245-1

Barbaroux R, Plasari E, Mercier G, Simonnot MO, Morel JL, Blais JF (2012) A new process for nickel ammonium disulfate production from ash of the hyperaccumulating plant Alyssum murale. Sci Total Environ 423:111-119. doi:10.1016/j.scitotenv.2012.01.063

Barrabe L, Maggia L, Pillon Y, Rigault F, Mouly A, Davis AP, Buerki S (2014) New Caledonian lineages of Psychotria (Rubiaceae) reveal different evolutionary histories and the largest documented plant radiation for the archipelago. Mol Phylogenet Evol 71:15-35. doi: 10.1016/j.ympev.2013.10.020

Bird ECF, Dubois J-P, Iltis J (1984) The impacts of opencast mining on the rivers and coasts of New Caledonia.

Bouchet P, Jaffre T, Veillon JM (1995) Plant extinction in NewCaledonia-protection of sclerophyll forests urgently needed. Biodivers Conserv 4:415-428

Bradshaw AD (1992) The biology of land restoration. In: Jain SK, Botsford LW (eds) Monographiae Biologicae, Vol 67 Applied Population Biology Ix+295p. Kluwer Academic Publishers, Dordrecht, pp 25-44

Bradshaw A (1997) Restoration of mined lands - using natural processes. Ecol Eng 8:255-269

Bradshaw AD Restoration after mining for metals - an ecological view. In: Jaffré T, Reeves RD, Becquer T (eds) Ecologie des milieux sur roches ultramafiques et sur sols métallifères., Nouméa, 1997b. Documents scientifiques et techniques. ORSTOM, pp 285-288.

Brooks RR, Chambers MF, Nicks LJ, Robinson BH (1998) Phytomining trends in plant science 3:359-362 doi:10.1016/s1360-1385(98) 01283-7.

Bustamante P, Grigioni S, Boucher-Rodoni R, Caurant F, Miramand P (2000) Bioaccumulation of 12 trace elements in the tissues of the nautilus Nautilus macromphalus from New Caledonia. Mar Pollut Bull 40:688-696

Chaintreuil C et al. (2007) Nickel resistance determinants in Bradyrhizobium strains from nodules of the endemic New Caledonia legume serianthes calycina Appl Environ Microbiol 73 doi:10.1128/aem.01431-07.

Chaney RL, Angle JS, Broadhurst CL, Peters CA, Tappero RV, Sparks DL (2007) Improved understanding of hyperaccumulation yields commercial phytoextraction and phytomining technologies. J Environ Qual 36:1429-1443. doi: 10.2134 jeq2006.0514

Cherrier JF (1990) Reconstitution of vegetative cover in mine areas in New Caledonia Bois et Forets des Tropiques:5-23

Clewell AF, Aronson J (2006) Motivations for the restoration of ecosystems. Conserv Biol 20:420-428. doi:10.1111/j.1523-1739.2006. 00340.x

Conesa HM, Evangelou MWH, Robinson BH, Schulin R (2012) A critical view of current state of phytotechnologies to remediate soils: still a promising tool? Scientific World Journal:10 doi:10.1100/ 2012/173829

Cunningham SD, Berti WR (1993) Remediation of contaminated soils with green plants - an overview. In Vitro Cell Dev Biol Plant 29P: 207-212

Danloux J, Laganier R (1991) Classification et quantification des phénomènes d'érosion, de transport et de sédimentation sur les bassins touchés par l'exploitation minière en Nouvelle Calédonie. ORSTOM, Nouméa

DIMENC (2008) Le schéma de mise en valeur des richesses minières de la Nouvelle-Calédonie. 
Dugain F (1953) Dégradation et protection des sols de la Nouvelle Calédonie

Dupon J-F (1986) Les effets de l'exploitation minière sur l'environnement des îles hautes: le cas de l'extraction du minerai de nickel en Nouvelle-Calédonie.

Ernst WHO (2000) Evolution of metal hyperaccumulation and phytoremediation hype. New Phytol 146:357-358. doi:10.1046/j. 1469-8137.2000.00669.x

Ernst WHO (2005) Phytoextraction of mine wastes - options and impossibilities. Chem derErde Geochem 65:29-42. doi:10.1016/j.chemer. 2005.06.001

Escande V, Olszewski TK, Grison C (2013) Preparation of ecological catalysts derived from $\mathrm{Zn}$ hyperaccumulating plants and their catalytic activity in Diels-Alder reaction Comptes Rendus Chimie

Escande V et al (2014a) Ecological catalysis and phytoextraction: symbiosis for future. Appl Catal B Environ 146:279-288. doi:10.1016/j. apcatb.2013.04.011

Escande V, Tomasz O, Eddy P, Grison C (2014b) Biosourced polymetallic catalysts: an efficient means yo synthesize underexploited platform molecules from carbohydrates. ChemSusChem. doi: $10.1002 /$ cssc. 201400078

Fernandez JM, Ouillon S, Chevillon C, Douillet P, Fichez R, Le Gendre R (2006) A combined modelling and geochemical study of the fate of terrigenous inputs from mixed natural and mining sources in a coral reef lagoon (New Caledonia). Mar Pollut Bull 52:320-331. doi:10. 1016/j.marpolbul.2005.09.010

Fernando DR, Marshall A, Baker AJM, Mizuno T (2013) Microbeam methodologies as powerful tools in manganese hyperaccumulation research: present status and future directions. Front Plant Sci 4:319. doi: $10.3389 /$ fpls.2013.00319

Fitamo D, Leta S (2010) Assessment of plants growing on gold mine wastes for their potential to remove heavy metals from contaminated soils. Int J Environ Stud 67:705-724

Florence TM, Stauber JL, Ahsanullah M (1994) Toxicity of nickel ores to marine organisms Science of the Total Environment 148 doi:10. 1016/0048-9697(94)90391-3.

Freyssinet P, Butt C, Morris R, Piantone P (2005) Ore-forming processes related to lateritic weathering. Econ Geol 100th Anniversary 1:681722

Fritsch E (2012) Les sols. In: Bonvallot J, Gay J-C, Habert E (eds) Atlas de la Nouvelle-Calédonie. IRD Editions, Nouméa, pp 73-76

Gauthier D, Navarro E, Rinaudo G, Jourand P, Jaffre T, Prin Y (1999) Isolation, characterisation (PCR-RFLP) and specificity of Frankia from eight Gymnostoma species endemic to New Caledonia. Eur J Soil Biol 35:199-205

Gillespie TW, Jaffre T (2003) Tropical dry forests in New Caledonia. Biodivers Conserv 12:1687-1697. doi:10.1023/a:1023649831355

Grandcolas P, Murienne J, Robillard T, Desutter-Grandcolas L, Jourdan H, Guilbert E, Deharveng L (2008) New Caledonia: a very old Darwinian island? Philos Trans R Soc B: Biol Sci 363:3309-3317

Grison C, Escande V (2012) Use of certain manganese-accumulating plants for carrying out organic chemistry reactions.

Grison C, Escande V (2013a) Use of certain manganese-accumulating plants for carrying out organic chemistry reactions. WO 2014/016509 A1.

Grison C, Escande V (2013b) Use of certain metal-accumulating plants for implementing organic chemistry reactions. WO 2013150197 A1.

Grison C, Escande V (2014) Use of particular metal accumulating plants for implementing catalyzed chemical reactions PCT/EP2014/ 053485 .

Grison C, Escarre J (2011a) Use of calcined plant/its part having accumulated at least one metal having zinc, nickel or copper to prepare composition having a metal catalyst for allowing the implementation of organic synthesis reactions e.g. halogenation of alcohols. WO2011064487-A1,
Grison C, Escarre J (2011b) Use of plant/its part having accumulated at least one metal having zinc, nickel or copper to prepare composition having a metal catalyst for allowing the implementation of organic synthesis reactions e.g. halogenation of alcohols. WO2011064462A1,

Grison CM, Escande V, Petit E, Garoux L, Boulanger C, Grison C (2013) Psychotria douarrei and Geissois pruinosa, novel resources for the plant-based catalytic chemistry. Rsc Adv 3:22340-22345. doi:10. 1039/c3ra43995j

Hedouin L, Pringault O, Metian M, Bustamante P, Warnau M (2007) Nickel bioaccumulation in bivalves from the New Caledonia lagoon: seawater and food exposure. Chemosphere 66:1449-1457. doi:10.1016/j.chemosphere.2006.09.015

Hery M, Philippot L, Meriaux E, Poly F, Le Roux X, Navarro E (2005) Nickel mine spoils revegetation attempts: effect of pioneer plants on two functional bacterial communities involved in the $\mathrm{N}$-cycle Environmental Microbiology 7 doi:10.1111/j.1462-2920.2004. 00705.x.

Hunt AJ et al (2014) Phytoextraction as a tool for green chemistry. Green Process Synth 3:3-22

Jaffré T (1980) Etude écologique du peuplement végétal des sols dérivés de roches ultrabasiques en Nouvelle Calédonie vol 124. Travaux et documents. ORSTOM, Paris.

Jaffre T (1993) The relationship between ecological diversity and floristic diversity in New Caledonia. Biodivers Lett 1:82-87

Jaffré T, Pelletier B (1992) Plantes de Nouvelle-Calédonie permettant de revégétaliser des sites miniers. Le Nickel - SLN, Nouméa

Jaffre T, Brooks RR, Lee J, Reeves RD (1976) Sebertia acuminata: a hyperaccumulator of nickel from New Caledonia. Science 193:579 580. doi:10.1126/science.193.4253.579

Jaffré T, Latham M, Schmid M (1977) Aspects de l'influence de l'extraction du minerai de nickel sur la végétation et les sols Cahiers ORSTOM - Série Biologie XII:307-321

Jaffré T, Rigault F, Sarrailh J-M (1994) La végétalisation des anciens sites miniers en Nouvelle-Calédonie Bois et forêts des tropiques:45-58

Jaffré T, Mc Coy S, Rigault F, Dagostini G Quelle méthode de végétalisation pour la réhabilitation des anciens sites miniers de Nouvelle-Calédonie. In: Jaffré T, Reeves RD, Becquer T (eds) Ecologie des milieux sur roches ultramafiques et sur sols métallifères., Nouméa, 1997. Documents scientifiques et techniques. ORSTOM, pp 285-288.

Jaffre T, Munzinger J, Lowry PP II (2010) Threats to the conifer species found on New Caledonia's ultramafic massifs and proposals for urgently needed measures to improve their protection. Biodivers Conserv 19:1485-1502. doi:10.1007/s10531-010-9780-6

Jaffre T, Pillon Y, Thomine S, Merlot S (2013) The metal hyperaccumulators from New Caledonia can broaden our understanding of nickel accumulation in plants. Front Plant Sci 4:279. doi: 10.3389/fpls.2013.00279

Jourand P, Hannibal L, Majorel C, Mengant S, Ducousso M, Lebrun M (2014) Ectomycorrhizal Pisolithus albus inoculation of Acacia spirorbis and Eucalyptus globulus grown in ultramafic topsoil enhances plant growth and mineral nutrition while limits metal uptake. J Plant Physiol 171:164-172. doi:10.1016/j.jplph.2013.10.011

Kamran MA et al (2014) The potential of the flora from different regions of Pakistan in phytoremediation: a review. Environ Sci Pollut Res 21:801-812. doi:10.1007/s11356-013-2187-7

Kappe CO (2000) Biologically active dihydropyrimidones of the Biginelli-type - a literature survey. Eur J Med Chem 35:1043-1052

Lagrange A (2009) Etudes écologique et microbiologique des espèces du genre Costularia (Cyperaceae) pionnières des sols ultramafiques de Nouvelle-Calédonie: applications à la restauration écologique. Université de Nouvelle, Calédonie

Lagrange A, L'Huillier L, Amir H (2013) Mycorrhizal status of Cyperaceae from New Caledonian ultramafic soils: effects of phosphorus availability on arbuscular mycorrhizal colonization of 
Costularia comosa under field conditions. Mycorrhiza 23:655-661. doi:10.1007/s00572-013-0503-1

Latham M (1971) L'influence de l'exploitation minière sur la dégradation des sols en Nouvelle-Calédonie

Latham M, Quantin P, Aubert G (1978) Etude des sols de la NouvelleCalédonie vol 78. Notice explicative. ORSTOM, Paris.

Lequesne Y (2014) Production de nickel et de cobalt par voie hydrométallurgique. Paper presented at the Recherche et innovation dans le traitement des ressources minérales, Paris.

L'Huillier L, Edighoffer S (1996) Extractability of nickel and its concentration in cultivated plants in $\mathrm{Ni}$ rich ultramafic soils of New Caledonia. Plant Soil 186:255-264. doi:10.1007/bf02415521

L'Huillier L et al. (2010) Mines et environnement en Nouvelle-Calédonie: les milieux sur substrats ultramafiques et leur restauration.

Losfeld G, de la Blache PV, Escande V, Grison C (2012a) Zinc hyperaccumulating plants as renewable resources for the chlorination process of alcohols Green Chemistry Letters and Reviews 5 doi: 10.1080/17518253.2012.667157.

Losfeld G, Escande V, Jaffre T, L'Huillier L, Grison C (2012b) The chemical exploitation of nickel phytoextraction: an environmental, ecologic and economic opportunity for New Caledonia. Chemosphere 89:907-910

Losfeld G, Escande V, Vidal de La Blache P et al (2012c) Design and performance of supported Lewis acid catalysts derived from metal contaminated biomass for Friedel-Crafts alkylation and acylation. Catal Today 189:111-116. doi:10.1016/j.cattod.2012.02.044

Lum AF, Ngwa ESA, Chikoye D, Suh CE (2014) Phytoremediation potential of weeds in heavy metal contaminated soils of the bassa industrial zone of douala, cameroon. Int J Phytoremediation 16:302319

Mayer TU, Kapoor TM, Haggarty SJ, King RW, Schreiber SL, Mitchison TJ (1999) Small molecule inhibitor of mitotic spindle bipolarity identified in a phenotype-based screen. Science 286:971-974. doi: 10.1126/science. 286.5441 .971

Merlot S, Hannibal L, Martins S, Martinelli L, Amir H, Lebrun M, Thomine S (2014) The metal transporter PgIREG1 from the hyperaccumulator Psychotria gabriellae is a candidate gene for nickel tolerance and accumulation J Exp Bot:eru025

Meyer J-Y, Loope LL, Sheppard A, Munzinger J, Jaffré T (2006) Les plantes envahissantes et potentiellement envahissantes dans l'archipel néo-calédonien: première évaluation et recommandations de gestion Les Espèces Envahissantes dans 1'Archipel NéoCalédonien, Part II:52-98

Migon C, Ouillon S, Mari X, Nicolas E (2007) Geochemical and hydrodynamic constraints on the distribution of trace metal concentrations in the lagoon of Noumea New Caledonia. Estuar Coast Shelf Sci 74: 756-765. doi:10.1016/j.ecss.2007.05.048

Mittermeier RA, Werner TA, Lees A (1996) New Caledonia: a conservation imperative for an ancient land. Oryx 30:104-112

Morat $\mathrm{P}$ et al (2012) The taxonomic reference base Florical and characteristics of the native vascular flora of New Caledonia. Adansonia 34:179-221

Mudd GM (2010) Global trends and environmental issues in nickel mining: sulfides versus laterites. Ore Geol Rev 38:9-26. doi:10. 1016/j.oregeorev.2010.05.003

Myers N (1988) Threatened biotas: "hot spots" in tropical forests. Environmentalist 8:187-208

Myers N, Mittermeier RA, Mittermeier CG, da Fonseca GAB, Kent J (2000) Biodiversity hotspots for conservation priorities. Nature 403: 853-858. doi:10.1038/35002501

Navarro E, Jaffre T, Gauthier D, Gourbiere F, Rinaudo G, Simonet P, Normand P (1999) Distribution of Gymnostoma spp. microsymbiotic Frankia strains in New Caledonia is related to soil type and to host-plant species. Mol Ecol 8:1781-1788

Oregon Department of Agriculture (2014) ODA Plant Programs, Noxious Weed Control yellow tuft (Alyssum murale, A. corsicum). http://
www.oregon.gov/ODA/PLANT/WEEDS/pages/weed_yellowtuft. aspx.

Ouillon S et al. (2010) Circulation and suspended sediment transport in a coral reef lagoon: the south-west lagoon of New Caledonia Mar Pollut Bull 61 doi:10.1016/j.marpolbul.2010.06.023.

Parker HL, Rylott EL, Hunt AJ, Dodson JR, Taylor AF, Bruce NC, Clark JH (2014) Supported palladium nanoparticles synthesized by living plants as a catalyst for Suzuki-Miyaura Reactions. PLoS ONE 9: e87192

Pascal M, Richer De Forges B, Le Guyader H, Simberloff D (2008) Mining and other threats to the New Caledonia biodiversity hotspot. Conserv Biol 22:498-499. doi:10.1111/j.1523-1739.2008.00889.x

Pelletier B (2006) Geology of the New Caledonia region and its implications for the study of the New Caledonian biodiversity Compendium of marine species from New Caledonia:17-30

Pillon Y (2012) Time and tempo of diversification in the flora of New Caledonia. Bot J Linn Soc 170:288-298. doi:10.1111/j.1095-8339. 2012.01274.X

Pillon Y, Munzinger J, Amir H, Lebrun M (2010) Ultramafic soils and species sorting in the flora of New Caledonia. J Ecol 98:1108-1116. doi:10.1111/j.1365-2745.2010.01689.x

Reeves RD (2003) Tropical hyperaccumulators of metals and their potential for phytoextraction. Plant Soil 249:57-65. doi:10.1023/ a: 1022572517197

Robinet O, Craig JL, Chardonnet L (1998) Impact of rat species in Ouvea and Lifou (Loyalty Islands) and their consequences for conserving the endangered Ouvea Parakeet. Biol Conserv 86:222-232

Robinson BH, Banuelos G, Conesa HM, Evangelou MWH, Schulin R (2009) The phytomanagement of trace elements in soil. Crit Rev Plant Sci 28:240-266. doi:10.1080/07352680903035424

Sas-Nowosielska A, Kucharski R, Malkowski E, Pogrzeba M, Kuperberg JM, Krynski K (2004) Phytoextraction crop disposal—an unsolved problem. Environ Pollut 128:373-379

SER (2004) The SER International Primer on Ecological Restoration. Society for Ecological Restoration International Tucson, AZ

Shu WS, Ye ZH, Zhang ZQ, Lan CY, Wong MH (2005) Natural colonization of plants on five lead/zinc mine tailings in Southern China. Restor Ecol 13:49-60. doi:10.1111/j.1526-100X.2005.00007.x

Smith RAH, Bradshaw AD (1979) Use of metal tolerant plantpopulations for the reclamation of metalliferous wastes. J Appl Ecol 16:595-612. doi:10.2307/2402534

Thillier Y, Losfeld G, Escande V, Dupouy C, Vasseur J-J, Debart F, Grison C (2013) Metallophyte wastes and polymetallic catalysis: a promising combination in green chemistry. The illustrative synthesis of 5 '-capped RNA. Rsc Advances 3:5204-5212. doi:10.1039/ c3ra23115a

Tordoff GM, Baker AJM, Willis AJ (2000) Current approaches to the revegetation and reclamation of metalliferous mine wastes. Chemosphere 41:219-228. doi:10.1016/s0045-6535(99)00414-2

UNESCO (2013) Lagoons of New Caledonia: reef diversity and associated ecosystems. http://whc.unesco.org/en/list/1115/. Accessed 02/ 052013

USGS (1996-2013) Mineral commodity summaries - Nickel.

van der Ent A, Baker AJM, Reeves RD, Pollard AJ, Schat H (2013a) Hyperaccumulators of metal and metalloid trace elements: facts and fiction. Plant Soil 362:319-334. doi:10.1007/s11104-012-1287-3

van der Ent A, Baker AJM, van Balgooy MMJ, Tjoa A (2013b) Ultramafic nickel laterites in Indonesia (Sulawesi, Halmahera): mining, nickel hyperaccumulators and opportunities for phytomining. $\mathrm{J}$ Geochem Explor 128:72-79

Whiting SN et al (2004) Research priorities for conservation of metallophyte biodiversity and their potential for restoration and site remediation. Restor Ecol 12:106-116. doi:10.1111/j.1061-2971. 2004.00367.x

Wilson-Corral V, Anderson CWN, Rodriguez-Lopez M (2012) Gold phytomining. A review of the relevance of this technology to 
mineral extraction in the 21st century. J Environ Manag 111:249257

Wong MH (2003) Ecological restoration of mine degraded soils, with emphasis on metal contaminated soils. Chemosphere 50: $775-780$

Wulff A, Hollingsworth PM, Haugstetter J, Piquet M, L'Huillier L, Fogliani B (2012a) Ten nuclear microsatellites markers cross-amplifying in Scaevola montana and S. coccinea (Goodeniaceae), a locally common and a narrow endemic plant species of ultramafic scrublands in New Caledonia. Conserv Genet Resour 4:725-728
Wulff AS, Turner SR, Fogliani B, L'Huillier L (2012b) Smoke stimulates germination in two divergent Gondwanan species (Hibbertia pancheri and Scaevola montana) endemic to the biodiversity hotspot of New Caledonia. Seed Sci Res 22:311-316

Wulff AS, Hollingsworth PM, Ahrends A, Jaffre T, Veillon J-M, L'Huillier L, Fogliani B (2013) Conservation priorities in a biodiversity hotspot: analysis of narrow endemic plant species in New Caledonia Plos One 8 doi:10.1371/journal.pone.0073371.

Ye ZH, Wong JWC, Wong MH, Baker AJM, Shu WS, Lan CY (2000) Revegetation of $\mathrm{Pb} / \mathrm{Zn}$ mine tailings, Guangdong Province. China Restor Ecol 8:87-92. doi:10.1046/j.1526-100x.2000.80012.x 